\title{
STATUS GIZI BADUTA PADA KELUARGA PENERIMA BERAS MISKIN (RASKIN) DI KELURAHAN TAIPA KECAMATAN PALU UTARA KOTA PALU
}

\author{
Children Under Two Nutrition Status of Raskin Recipient Family In Taipa, \\ North Palu, Palu
}

\author{
Amsal \\ Poltekkes Kemenkes Palu \\ (amsal@gmail.com)
}

\begin{abstract}
ABSTRAK
Penelitian ini bertujuan untuk mengetahui gambaran status gizi baduta pada keluarga penerima raskin di Kelurahan Taipa Kecamatan Palu Utara Kota Palu. Penelitian deskriptif. Dilakukan di kelurahan Taipa Kecamatan Palu Utara pada tanggal 28-30 Juli 2018. Populasi adalah seluruh baduta pada keluarga yang menerima raskin di kelurahan Taipa Kecamatan Palu Utara kota palu yang berjumlah 38 orang. Sampel menggunakan total populasi sebanyak 38 anak baduta. Hasil penelitian menunjukkan bahwa 34,2\% Kepala keluarga berpendidikan tamat SLTP/MTS. Bekerja sebagai pekerja harian 23 orang $(60,5 \%)$ dan sebagai buruh yaitu 14 orang $(36,8 \%)$. Baduta pada keluarga penerima raskin yang mempunyai masalah gizi kurang berjumlah 10 baduta $(26,3 \%)$ dan gizi buruk 2 orang $(5,3 \%)$. Postur tubuh Sangat Pendek berjumlah 4 baduta $(10,5 \%)$ dan pendek 6 orang $(15,8 \%)$. Baduta yang sangat kurus sebanyak 2 baduta $(5,3 \%)$ dan kurus berjumlah 6 baduta $(15,8 \%)$. Kesimpulan dan saran; status gizi dari 38 orang anak Baduta keluarga penerima raskin yaitu gizi kurang 26,3\%, gizi buruk 5,3\%. Sangat pendek 10,5\%, pendek 15,8\%. Sangat kurus 5,3\% dan kurus $15,8 \%$. Disarankan agar selain memperoleh beras miskin, keluarga baduta juga memperoleh Makanan tambahan khusus untuk baduta di setiap keluarga agar status gizi baduta menjadi lebih baik.
\end{abstract}

Kata kunci: Status gizi, baduta, beras miskin

\section{ABSTRACT}

This research aims to determine the nutrition status in families of Raskin rescipient in Taipa, North Palu, Palu. This research is a descriptive research. This research was conducted in the Taipa sub-district of North Palu District on July 28th - July 30th, 2018. The population was 38 baduta of families who received raskin in Taipa. The sample was a total population of 38 baduta. The results showed that $34.2 \%$ were householder who had graduated from middle high. Those who work as daily workers were 23 people (60.5\%) and as laborers were 14 people (36.8\%). Baduta in raskin recipient families who have low nutrition were 10 badutas (26.3\%) and malnutrition were 2 badutas (5.3\%). Very short were 4 badutas $(10.5 \%)$ and short were 6 badutas (15.8\%). Very thin were badutas 2 (5.3\%) and thin was 6 baduta (15.8\%). As conclusion, the nutritional status of 38 Baduta from the Raskin recipient family are; malnutrition $26.3 \%$, malnutrition $5.3 \%$, very short $10.5 \%$, short $15.8 \%$, very thin $5.3 \%$ and thin $15.8 \%$. The researcher suggest that baduta families should obtain additional food, beside the raskin, for their better nutrition status.

Keywords: Nutrition status, children under two, raskin 


\section{PENDAHULUAN}

Periode 0-2 tahun Merupakan periode kritis pada masa pertumbuhan atau disebut sebagai periode emas ${ }^{(1)}$. Pada masa tersebut juga sering terjadi masalah gizi. Di seluruh dunia anak yang menderita stunting sebanyak $22,9 \%$, overweight $6,0 \%$ dan wasting $7,7 \%$. Di Asia stunting sebanyak 87 juta anak, overweight 20 juta, wasting 36 juta $^{(2)}$. Data Indonesia tahun 2016 menunjukkan stunting sebanyak 27,5\%, Obesitas 4,3\%, wasting $11,1 \%^{(3)}$. Di Sulawesi Tengah dari tahun 2011 sampai tahun 2015 jumlah penderita gizi buruk berturut-turut 473 orang, 657 orang, 442 orang, 521 orang dan 569 orang $^{(4)}$.

Penerimaan beras untuk orang miskin (raskin) secara teratur diharapkan dapat membantu masyarakat miskin untuk mencukupi ketersediaan pangan pokoknya secara berkala ${ }^{(5)}$. Kemiskinan tidak selalu paralel dengan status gizi, sebagai contoh, penduduk miskin di Kabupaten Jeneponto dan Selayar, Sulawesi Selatan, jumlahnya relatif sama dan lebih tinggi dari angka nasional. Namun, Jeneponto memiliki prevalensi balita gizi-kurang yang tinggi (28\%), sedangkan Selayar memiliki prevalensi balita gizi-kurang yang rendah $(11,3 \%)^{(6)}$. Konsumsi pangan dipengaruhi oleh faktor ekonomi dan harga, serta faktor sosio-budaya dan religi ${ }^{(7)}$. Penelitian di Situbondo menunjukkan ada hubungan antara tingkat konsumsi energi dan lemak dengan status gizi anak usia 2-5 tahun anak Gakin ${ }^{(8)}$. Berdasarkan data profil kesehatan Mamboro tahun 2016 jumlah balita yaitu, 335 balita. Status gizi balita gizi buruk 2 balita terdapat di Mamboro 1 balita dan di Taipa 1 balita. Sedangkan gizi kurang berjumlah 68 balita yang terdapat di Mamboro induk 28 balita, Mamboro barat 18 balita dan Taipa 21 balita. Data BPS Sulawesi Tengah menunjukan rumah tangga penerima raskin dalam pagu Sulawesi Tengah tidak banyak berubah yaitu 159.126 (2011) 210.501 (2012), 201.239 (2013), 201.239 (2014), kemudian 201.239 (2015) $^{(9)}$. Data Kantor Kecamatan Palu Utara tentang jumlah Keluarga Penerima Manfaat (KPM) tahun 2017 menunjukkan kelurahan yang paling banyak menerima bantuan raskin adalah kelurahan Taipa yang berjumlah 458 KPM.

Penelitian ini bertujuan untuk mengetahui gambaran status gizi baduta pada keluarga penerima raskin di Kelurahan Taipa Kecamatan Palu Utara Kota Palu.

\section{METODE PENELITIAN}

Penelitian deskriptif. Dilakukan di kelurahan Taipa Kecamatan Palu Utara pada tanggal 28-30 Juli 2018. Populasi adalah seluruh baduta pada keluarga yang menerima raskin di kelurahan Taipa Kecamatan Palu Utara kota palu yang berjumlah 38 orang. Sampel menggunakan total populasi sebanyak 38 anak baduta.

\section{HASIL}

Letak geografis Kelurahan Taipa terdiri dari lima dusun diantaranya adalah Taipa Laga, Taipa Ramba, Taipa Ginggiri, Taipa Vatu Oge, dan Taipa Labuan Beru. Kelurahan Taipa terletak pada letak koordinat Lintang 
Selatan $0^{\circ} 43^{\prime} 48$ dan $0^{\circ} 50^{\prime} 00$ dan Bujur Timur 11955'00. Sebelah Utara berbatasan dengan Kelurahan Kayumalue Pajeko dan kelurahan Kayumalue Ngapa, sebelah timur berbatasan dengan Desa Guntarano, sebelah selatan berbatasan dengan kelurahan Mamboro Barat, sebelah Barat berbatasan dengan Teluk Palu.

Hasil penelitian menunjukkan sebagian besar kepala keluarga berpendidikan tamat SLTP/MTS yaitu 13 orang $(34,2 \%)$ sebagai pekerja harian yaitu 23 orang $(60,5 \%)$ dan sebagai buruh yaitu 14 orang $(36,8 \%)$. Sebagian besar baduta pada keluarga penerima raskin adalah berjenis kelamin perempuan yaitu $26(68,4 \%)$. baduta pada keluarga penerima raskin yang mempunyai masalah gizi terbanyak yaitu gizi kurang yang berjumlah 10 baduta $(26,3 \%)$ dan baduta yang memiliki status gizi buruk berjumlah 2 orang $(5,3 \%)$. Sangat Pendek berjumlah 4 baduta $(10,5 \%)$ dan pendek 6 orang $(15,8 \%)$. Masalah gizi yaitu sangat kurus berjumlah 2 baduta $(5,3 \%)$, kurus berjumlah 6 baduta $(15,8 \%)$ dan gemuk berjumlah 1 baduta $(2,6 \%)$.

Tabel 1. Karakteristik Kepala keluarga baduta pada Keluarga Penerima Raskin Di Kelurahan Taipa Kecamatan Palu Utara

\begin{tabular}{lcc}
\hline \multicolumn{1}{c}{ Karakateristik } & n & \% \\
\hline Pendidikan KK & & \\
Tidak/belum pernah sekolah & 0 & 0,0 \\
Tidak tamat SD/MI & 0 & 0,0 \\
Tamat SD/MI & 12 & 31,6 \\
Tamat SLTP/MTS & 13 & 34,2 \\
Tamat SLTA/MA & 13 & 34,2 \\
Perguruan Tinggi (DI-III/SI) & 0 & 0,0 \\
Pekerjaan KK & & \\
Buruh & 14 & 36,8 \\
Pekerja Harian & 23 & 60,5 \\
Pedagang & 1 & 2,6 \\
\hline Sumbr: Data Primer, &
\end{tabular}

Sumber : Data Primer, 2018.
Tabel 2. Status Gizi dan Jenis Kelamin Baduta Keluarga Penerima Raskin di Kelurahan Taipa Kecamatan Palu Utara

\begin{tabular}{lcc}
\hline \multicolumn{1}{c}{ Karakateristik } & n & \% \\
\hline Jenis Kelamin & & \\
$\quad$ Laki - laki & 12 & 31,6 \\
$\quad$ Perempuan & 26 & 68,4 \\
Indikator Berat Badan & & \\
Menurut Umur (BB/U) & & \\
$\quad$ Gizi Buruk & 2 & 5,3 \\
$\quad$ Gizi Kurang & 10 & 26,3 \\
$\quad$ Gizi Baik & 26 & 68,4 \\
$\quad$ Gizi Lebih & 0 & 0,0 \\
Indikator Panjang Badan & & \\
Menurut Umur (PB/U) & & \\
$\quad$ Sangat Pendek & 4 & 10,5 \\
$\quad$ Pendek & 6 & 15,8 \\
$\quad$ Normal & 26 & 68,4 \\
$\quad$ Tinggi & 2 & 5,3 \\
Indikator Berat Badan & & \\
Menurut Panjang Badan & & \\
(BB/PB) & & \\
$\quad$ Sangat Kurus & 2 & 5,3 \\
Kurus & 6 & 15,8 \\
$\quad$ Normal & 29 & 76,3 \\
$\quad$ Gemuk & 1 & 2,6 \\
\hline Sumber : Data Primer, 2018 & &
\end{tabular}

Sumber : Data Primer, 2018

\section{PEMBAHASAN}

Pada penelitian ini penentuan status gizi berdasarkan tiga parameter yaitu: Status Gizi menurut berat badan menurut Umur $(\mathrm{BB} / \mathrm{U})$, panjang badan menurut umur $(\mathrm{PB} / \mathrm{U})$ dan Berat badan menurut panjang badan (BB/PB). Tabel 2 menunjukkan status gizi baduta pada keluarga penerima raskin berdasarkan indeks $\mathrm{BB} / \mathrm{U}$ berstatus gizi kurang 10 baduta $(26,3 \%)$, dan gizi buruk berjumlah 2 baduta $(5,3 \%)$. berstatus gizi baik yaitu 26 orang $(68,4 \%)$. Hasil penelitian diatas didapatkan sebagian besar status gizi baduta normal dikarenakan baduta pada keluarga penerima raskin kecukupan pangannya terpenuhi serta keadaan lingkungan dan kesehatan baduta tidak terganggu ada pun baduta yang menderita gizi 
kurang dan gizi buruk dikarenakan badutanya sedang sakit atau pola asuh serta keadaan lingkungan yang kurang memadai karena penyebab timbulnya masalah gizi pada baduta ada faktor-faktor yang mempengaruhinya yaitu, diantaranya adalah penyebab langsung dan penyebab tidak langsung. Faktor penyebab langsung yaitu makanan dan penyakit infeksi yang mungkin diderita oleh anak. Penyebab tidak langsung diantaranya adalah pola pengasuhan anak, pelayanan kesehatan serta kesehatan lingkungan, dan ketahanan pangan dalam keluarga, Pemerintah sudah berupaya dengan memberikan beberapa bantuan kepada masyarakat yang tergolong miskin, salah satunya adalah bantuan pangan berupa bantuan raskin. Penerimaan raskin secara tertur diharapkan dapat membantu ketersediaan pangan rumah tangga miskin tercukupi terutama pangan pokok dalam hal ini beras ${ }^{(10)}$.

Status gizi menurut $\mathrm{PB} / \mathrm{U}$, dari hasil penelitian didapatkan bahwa status gizi baduta pada keluarga penerima raskin secara umum berdasarkan indeks Panjang Badan Menurut Umur $(\mathrm{PB} / \mathrm{U})$, berdasarkan hasil distribusi frekuensi dari tabel 2 terlihat bahwa baduta pada keluarga penerima raskin dari 38 baduta memiliki status gizi sangat pendek 4 baduta $(10,5 \%)$, pendek 6 baduta $(15,8)$, tinggi 2 baduta $(5,3 \%)$ dan baduta normal berjumlah 26 orang $(68,4 \%)$ yang berarti baduta pada keluarga penerima raskin sebagian besar status gizinya baik.

Hasil penelitian ini sejalaan dengan hasil penelitian yang di lakukan Eda Mirip bahwa keluarga yang berpendapatan rendah sebanyak 79 keluarga $(84,9 \%)$ terdapat 2 keluarga $(2,2 \%)$ memiliki bayi berstatus gizi sangat pendek, sebanyak 9 keluarga $(9,7 \%)$ memiliki bayi berstatus gizi pendek dan sebanyak 68 keluarga $(73,1 \%)$ memiliki bayi berstatus gizi normal $^{(11)}$.

Penelitian yang di lakukan Eda Mirip sejalan dengan penelitian ini yang berarti baduta pada keluarga penerima raskin status gizinya normal karena masalah status gizi baduta tidak dilihat hanya dengan satu faktor penyebab saja karena penyebab masalah gizi ada beberapa faktor diantaranya makanan, penyakit infeksi, pola asuh pelayanan kesehatan, kesehatan lingkungan dan ketahan pangan.

Status gizi menurut (BB/PB/TB), Dari hasil penelitian didapatkan bahwa status gizi baduta pada keluarga penerima raskin secara umum berdasarkan indeks Berat Badan menurut Panjang Badan (PB/TB), Berdasarkan hasil distribusi frekuensi dari tabel 2 terlihat bahwa baduta pada keluarga penerima raskin dari 38 baduta memiliki status gizi sangat kurus berjumlah 2 baduta $(5,3 \%)$ kurus berjumlah 6 baduta $(15,8 \%)$ dan gemuk berjumlah 1 baduta $(2,6 \%)$ kemudian status gizi normal berjumlah 29 baduta (76,3\%). Pada penelitian Eda Mirip juga menjelaskan bahwa keluarga yang berpendapatan rendah sebanyak 79 keluarga $(84,9 \%)$, terdapat 7 keluarga $(7,5 \%)$ memiliki bayi berstatus gizi kurus dan sebanyak 65 keluarga $(69,9 \%)$ memiliki bayi berstatus gizi normal ${ }^{(5)}$. Sejalan 
dengan penelitian ini yang berarti keluarga berpendapatan rendah atau keluarga penerima raskin memiliki bayi atau baduta status gizi nya normal hal ini dikarenakan status ekonomi rendah dan penerima raskin pada keluarga bayi atau baduta tidak terlalu berpengaruh terhadap status gizi bayi maupun balitanya dan penyebab masalah gizi ada beberapa faktor ada pun penelitian ini hanya salah satu faktor penyebab masalah gizi pada bayi, baduta maupun balita adapun faktor tersebut yaitu ketersediaan pangan keluarga.

Raskin yang diterima secara teratur dapat menjamin ketersediaan pangan pokok, berupa beras, di rumah tangga tersebut tercukupi secara stabil ${ }^{(5)}$. Keteraturan penerimaan raskin di wilayah kelurahan taipa tentunya telah menjamin ketersediaan pangan pangan berupa beras di rumah tangga hal tersebut tentunya berdampak pada status gizi keluarga sehingga status gizi balita rata rata normal dan baik.

Penelitian di Banda Aceh menunjukan bahwa pada keluarga miskin 40,3\% tingkat ketersediaan pangan terjamin, sedangkan $59,7 \%$ berada pada rawan pangan. Konsumsi energi untuk anak balita umur 1-3 tahun sebanyak 50\% telah mengkonsumsi sesuai dengan kebutuhan yang telah dianjurkan yaitu 1250 Kkal. Untuk anak balita umur 4-5 tahun $87,5 \%$ konsumsi energinya kurang dari yang dianjurkan (1750 Kkal). Konsumsi protein pada anak balita umur 4-5 tahun lebih besar kekurangan protein $(75 \%)$ dibanding pada anak balita 1-3 tahun (37,7\%). Status gizi balita menurut umur, dari 30 sampel usia 1-3 tahun $60 \%$ mempunyai status gizi baik, 36,7\% status gizi kurang, dan 3,3, \% status gizi buruk. Pada kelompok umur 4-5 tahun status gizi kurang terbanyak $75 \%$, gizi baik 18,8 dan status gizi buruk $6,3 \%{ }^{(12)}$.

Pola makan anak balita pada keluarga miskin di Kelurahan Kenangan Baru, Perumnas Mandala sebagian besar kurang bervariasi, hanya mengonsumsi makanan pokok berupa nasi dengan lauk pauk, konsumsi sayur dan buah juga masih sangat terbatas. Pola makan yang tidak lengkap dan konsumsi zat gizi pada kategori kurang sebagian besar pada kelompok umur 37-60 bulan. Status gizi pada kategori kurang sebagian besar terdapat pada kelompok umur 37-60 bulan. Status gizi baik memiliki pola makan yang lengkap dan konsumsi zat gizi pada kategori baik sedangkan status gizi kurang memiliki pola makan yang tidak lengkap dan konsumsi zat gizi pada kategori kurang ${ }^{(13)}$. Hasil penelitian Herlistiah menunjukkan bahwa sanitasi rumah lebih berkontribusi terhadap status gizi bayi pada keluarga miskin perkotaan jika dibandingkan pemberian Makanan Pendamping ASI (MP-ASI) ${ }^{(14)}$.

Hasil Penelitian Luciasari menunjukkan bahwa status gizi balita sangat ditentukan oleh faktor sosial dan ekonomi keluarga meliputi pendidikan kepala keluarga (KK) dan ibu, penghasilan $\mathrm{KK}$, jumlah anggota rumah tangga, akses air bersih, kebersihan dan sanitasi lingkungan serta morbiditas keluarga ${ }^{(6)}$.

Penelitian ini mencatat bahwa penyaluran 
beras sudah cukub baik baik jumlah dan waktunya. Studi di Minahasa menunjukkan implementasi kebijakan penyaluran beras rakyat miskin belum optimal dimana sasaran, harga, jumlah, dan admintrasi belum tepat, dan kualitas beras yang disalurkan belum sesuai dengan kualitas medium yang ditetapkan pemerintah, meskipun waktu penyaluran beras sudah lancar ${ }^{(15)}$. Studi lain di Kecamatan Kunto Darussalam Riau, menunjukan bahwa Manfaat Program Beras Miskin (Raskin) belum maksimal dirasakan oleh RTS-PM, serta pendistribusian yang mengalami keterlambatan, dengan rentang waktu pendistribusian satu kali dalam dua bulan ${ }^{(16)}$. Penelitian di Kecamatan Banyumanik, Semarang juga masih kurang optimal. Indikator yang dirasa masih kurang diantaranya adalah upaya kebijakan yang belum tepat sasaran, penerimaan beras masyarakat yang tidak sesuai dengan jumlah seharusnya, ketersediaan sumber daya yang masih kurang, sasaran penerima yang tidak tepat sasaran ${ }^{(17)}$.

\section{KESIMPULAN DAN SARAN}

Masalah status Gizi 38 orang anak Baduta keluarga penerima raskin yaitu status gizi kurang 26,3\%, gizi buruk 5,3\%. Sangat pendek $10,5 \%$, pendek $15,8 \%$. Sangat kurus 5,3\% dan kurus $15,8 \%$. Disarankan agar selain memperoleh beras miskin, keluarga baduta juga memperoleh Makanan tambahan khusus untuk baduta di setiap keluarga agar status gizi baduta menjadi lebih baik.

\section{UCAPAN TERIMA KASIH}

Terima kasih kepada Direktur Poltekkes Kemenkes Palu, Enumerator dan responden penelitian di Kelurahan Taipa Kota Palu.

\section{DAFTAR PUSTAKA}

1. Adriani M, Wirjatmadi B. Peranan Gizi dalam Siklus Kehidupan. Jakarta:

Kencana Prenadamedia Group; 2012.

2. Development Intiatives. Global Nutrition Report Nourishing the SDGs. Bristol; 2017.

3. Kemenkes RI. Hasil Pemantauan Status Gizi (PSG) dan Penjelasannya Tahun 2016. Jakarta; 2016.

4. Dinkes Provinsi Sulteng. Profil Kesehatan Provinsi Sulawesi Tengah Tahun 2015. Palu; 2015. 1-170 p.

5. Santi, Andrias DR. Hubungan Ketersediaan Pangan dan Keteraturan Penerimaan Raskin Dengan Status Ketahanan Pangan Rumah Tangga Penerima Raskin. Media Gizi Indones. 2015;10(2):97-103.

6. Luciasari E, Permanasari Y, Almasyhuri. Faktor-faktor penyimpangan Postif (Positive Deviance) Status Gizi Balita pada Keluarga Miskin di Kabupaten Gizi Kurang Rendah dan Tinggi di Provinsi Sulawesi Selatan. J Penelit Gizi dan Makanan. 2011;34(2):114-22.

7. Hardinsyah M, Supariasa IDN. Ilmu Gizi Teori dan Aplikasi. I. Hardinsyah, Supariasa D, editors. Jakarta: Penerbit Buku Kedokteran EGC; 2016.

8. Thohirun, Sulistiyani, Wahyuningrum RM. Tingkat Konsumsi dan Status Gizi Anak Usia 2-5 Tahun pada Keluarga Miskin di Daerah Pesisir Situbondo. Ikesma [Internet]. 2010;6(1). Available from: http://jurnal.unej.ac.id/index.php/IKESM A/article/view/1640

9. Massa A. Pagu raskin Sulteng 2015 tidak berubah. Antara Sulteng. 2015;2.

10. Hastuti, Sulaksono B, Mawardi S. Tinjauan Efektivitas Pelaksanaan Raskin dalam Mencapai Enam Tepat Tinjauan Efektivitas Pelaksanaan Raskin dalam Mencapai Enam Tepat. Lembaga 
Penelitian Smeru Research Institute. 2012.

11. Mirip E, Punuh MI, Malonda NSH. Hubungan Antara Status Sosial Ekonomi dengan Status Gizi pada Bayi Usia 6-12 Bulan di Puskesmas Kolongan Kecamatan Kalawat Kabupaten Minahasa Utara. J KESMAS [Internet]. 2015;2(1):1-9. Available from: https://ejournalhealth.com/index.php/kes mas/article/viewFile/475/463

12. Maryam S, Gani FA. Gambaran tingkat Ketersediaan Pangan Keluarga dan Status Gizi Balita pada Keluarga Miskin di Desa Lambaro Skep Kecamatan Kuta Alam Kota Banda Aceh. JESBIO. 2015;IV(2):23-8.

13. Aidina CN, Lubis Z, Ardiani F. Pola Makan,Kecukupan Gizi, dan Status Gizi Balita pada Keluarga Miskin, Kalurahan Kenangan Baru. J Gizi, Kesehat Reproduksi dan Epidemiol [Internet]. 2010;1(4):1-8. Available from: https://jurnal.usu.ac.id/index.php/gkre/arti cle/view/11385

14. Herlistia BHR, Muniroh L. Hubungan Pemberian Makanan Pendamping ASI (MP-ASI) dan Sanitasi Rumah dengan Status Gizi Bayi Keluarga Miskin
Perkotaan. Media Gizi Indones [Internet]. 2016;10(1):76-83. Available from: https://ejournal.unair.ac.id/MGI/article/view/3130

15. Mangende HD, Rumapea P, Palar N. Implementasi Kebijakan Penyaluran Beras Rakyat Miskin Di Desa Poopoh Kecamatan Tombariri Kabupaten. J Adm Publik [Internet]. 2016;1(37):1-10. Available from: https://ejournal.unsrat.ac.id/index.php/JA P/article/view/11761

16. S RS. Implementasi Program Beras Miskin untuk Masyarakat Miskin di Kelurahan Kota Lama Kecamatan Kunto Darusalam. J Online Mhs Bid Ilmu Sos dan Ilmu Polit [Internet]. 2016;3(2):1-10. Available from: https://jom.unri.ac.id/index.php/JOMFSIP /article/view/9848/9510

17. Nugraha DP, Santoso RS. Implementasi Program Beras Miskin di Wilayah Kelurahan Pudakpayung Kecamatan Banyumanik Kota Semarang. J Public Policy Manag Rev [Internet]. 2017;6(1):1-19. Available from: https://ejournal3.undip.ac.id/index.php/jp pmr/article/view/14564/14089 